\title{
Analisis kemampuan berpikir kritis matematis siswa ditinjau dari self confidence
}

\author{
Pramudya Hilma Khoirunnisa, Putri Nur Malasari \\ Tadris Matematika, Fakultas Tarbiyah, Institut Agama Islam Negeri Kudus, Kudus, Indonesia \\ E-mail: putrinurmalasari@iainkudus.ac.id
}

\begin{abstract}
ABSTRAK
Penelitian ini ditujukan guna menganalisis dan mendeskripsikan kemampuan berpikir kritis matematis siswa kelas X SMK Negeri 1 Kudus berdasarkan tingkat selfconfidence yang dimiliki. Subjek yang digunakan yaitu 3 peserta didik kelas $X j$ urusan Akuntansi SMK Negeri 1 Kudus dimana ketiganya memiliki tingkat kepercayaan diri yang berbeda, yaitu tinggi, sedang, dan rendah. Penelitian ini merupakan penelitian eksploratif dengan pendekatan deskriptif kualitatif. Pengumpulan data dilakukan dengan memberikan angket self-confidence, tes kemampuan berpikir kritis, serta wawancara. Untuk menganalisis data, teknik yang digunakan yaitu reduksi data, penyajian data, dan penarikan kesimpulan. Sedangkan untuk keabsahan data digunakan teknik triangulasi waktu. Dari penelitian ini dapat ditarik kesimpulan bahwa semakin tinggi tingkat self-confidence peserta didik maka semakin baik pula kemampuan berpikir kritis matematis peserta didik tersebut, begitupun sebaliknya.
\end{abstract}

Kata kunci: berpikir kritis matematis; pendidikan matematika; self-confidence

\begin{abstract}
This study is aimed at analyzing and describing the mathematical critical thinking skills of grade X students of SMK Negeri 1 Kudus based on their level of self-confidence. The subjects used were 3 grade X students majoring in Accounting at SMK Negeri 1 Kudus where the three of them had different levels of self-confidence, namely high, medium, and low. This research is an exploratory research with a qualitative descriptive approach. Data collection was carried out by providing self-confidence questionnaires, tests of critical thinking skills, and interviews. To analyze the data, the techniques used were data reduction, data presentation, and conclusion drawing. While for data validity, time triangulation technique is used. From this research it can be concluded that the higher the level of self-confidence of students, the better the students' mathematical critical thinking skills, and vice versa.
\end{abstract}

Keywords: mathematical critical thinking; mathematics education; self-confidence

\section{PENDAHULUAN}

Perkembangan IPTEK (Ilmu Pengetahuan dan Teknologi) yang pesat menuntut pendidikan agar menciptakan SDM berkualitas tinggi yang dapat berpikir kritis, sistematis, logis, dan kreatif sehingga dapat menyelesaikan berbagai permasalahan yang ada. Matematika adalah cabang ilmu yang berperan penting pada bidang pendidikan dan kemampuan berpikir kritis adalah komponen yang mendasar dalam potensi matematis yang perlu diajarkan kepada siswa sehingga dapat meningkatkan pola pikir yang dimiiki dan dapat eksis di lingkup global (Purwati, 2019). 
Danaryanti \& Lestari (2017) mengemukakan bahwa kemampuan berpikir kritis berarti kemampuan individu dalam beraktivitas yang menjadikan individu tersebut mampu berpikir kritis. Sedangkan menurut Ennis (dalam Agusman, 2016; Muhtadi, at al., 2019), berpikir kritis sendiri adalah aktivitas mental yang berkontribusi dalam perumusan dan pemecahan permasalahan sehari-hari, serta pengambilan keputusan terkait hal-hal yang perlu diyakini dan dikerjakan. Paul \& Elder (dalam Widana, 2017) juga mendeskripsikan berpikir kritis seolah seni guna mengembangkan kemampuan berpikir dalam menganalisa dan mengevaluasi penyelesaian suatu masalah. Sedangkan Paul dan Elder (dalam Manfaati, 2017), mendefinisikan berpikir kritis sebagai langkah berpikir terkait segala permasalahan yang mana individu disebut kritis jika mampu berpikir melebihi batas kecerdasannya. Individu akan lebih berkualitas pemikirannya jika berpikir melebihi standar intelektual yang dimilikinya.

Dengan matematika, peserta didik diberi peluang untuk menerapkan keterampilan berpikirnya sehingga perkiraan-perkiraannya dapat mengacu pada pengetahuan dan pengalaman yang dimiliki, serta lebih mudah dalam memahami konsep. Dengan melatih kemampuan berpikir kritis siswa akan menjadikannya mampu mengkaji setiap masalah di kehidupannya. Berpikir kritis mampu membuat peserta didik lebih peka terhadap keadaan, sehingga peserta didik mampu memilah informasi yang diterimanya. Berpikir kritis bisa disebut keterampilan berpikir secara reflektif guna menentukan keputusan/tindakan dimana kemampuan berpikir kritis tentu berbeda antara peserta didik satu dengan lainnya. Maka dari itu, sudah seharusnya pendidik melatih dan mengembangkan kemampuan berpikir kritis yang dimiliki siswa dalam proses pembelajaran.

Hasil survei Internasional Programme for International Student Assessment (PISA) 2015 pada bidang matematika menunjukkan Indonesia menempati urutan 64 dari 72 negara partisipan dimana rata-rata skornya 386 (OECD dalam Agryvita dkk., 2019). Hasil survei memperlihatkan bahwa siswa di Indonesia mempunyai kemampuan berpikir kritis yang minim (Nurkholifah dkk, 2018). Masalah tersebut disebabkan kesulitan siswa dalam menyelesaikan soal tipe berpikir kritis yang belum terbiasa diterimanya (Tresnawati dkk, 2017). Facione (dalam Zetriuslita dkk, 2016: 57) mengungkapkan bahwa berpikir kritis memiliki konsep dasar yaitu interpretasi, analisis, evaluasi, penyimpulan, penjelasan dan kepercayaan diri. Dengan kata lain, untuk mencapai kemampuan berpikir kritis matematis dibutuhkan adanya kepercayaan diri (self-confidence) pada siswa agar perasaan cemas dan ragu tidak menghampirinya (Hajar dan Minarti (2019). Hoffman \& Schraw (dalam Agryvita dkk., 2019) mengemukakan bahwa faktor kepribadian berpengaruh pada peningkatan kemampuan berpikir kritis, salah satunya yaitu self-confidence (kepercayaan diri).

Septiani dkk. (2018) mendefinisikan self-confidence sebagai suatu keyakinan diri atas potensi yang dimiliki maupun segala kejadian di hidupnya. Self-confidence adalah keyakinan individu untuk dapat menyelesaikan permasalahan yang dihadapi dalam keadaan terbaiknya serta mampu membagikan hal menjadikan senang orang lain (Martyanti, 2013). Self-confidence juga bisa dipahami sebagai daya juang individu ketika menghadapi masalah yang harus diselesaikan (Hidayat, 2017).

Hajar dan Minarti (2019) dalam penelitiannya pada siswa kelas IX di salah satu SMP swasta di Kota Cimahi mengungkapkan bahwa siswa cenderung memiliki tingkat kemampuan berpikir kritis matematis rendah yang diakibatkan karena kurangnya rasa percaya diri (selfconfidence) ketika menghadapi matematika. Sedangkan penelitian yang dilakukan oleh Siti Nurkholifah, dkk. (2018) mengungkapkan bahwa tingkat kepercayaan diri siswa berbanding lurus dengan kemampuan berpikir kritisnya. Selain itu, Tresnawati, dkk. (2017) dalam penelitiannya juga mengungkapkan bahwa self-confidence memengaruhi 
kemampuan berpikir kritis matematis siswa SMA di kota Bandung sebesar 74,6\%, dan sisanya $25,4 \%$ mendapat pengaruh dari faktor lain.

Dari beberapa penelitian tersebut memperlihatkan bahwa self-confidence dibutuhkan dalam pembelajaran matematika. Namun urgensi self-confidence terhadap peserta didik dalam belajar matematika nyatanya berbeda dengan yang terjadi sebenarnya di Indonesia. Survei menunjukkan ada 52\% peserta didik dengan kepercayaan diri sedang, 45\% rendah, dan 3\% saja yang tergolong tinggi (Martyanti, 2013). Begitu pula yang terjadi dengan siswa kelas X SMK Negeri 1 Kudus dimana terlihat pada keraguan dan ketidakmampuan siswa ketika menyelesaikan persoalan matematika yang membutuhkan kemampuan berpikir kritis. Jadi dapat dikatakan bahwa siswa masih kurang menyadari urgensi dari selfconfidence yang dimilliki terhadap kemampuan berpikir kritisnya.

Berdasarkan hal tersebut, maka dibutuhkan adanya penelitian guna melihat seperti apa deskripsi keterkaitan yang dikontribusikan self-confidence terhadap kemampuan berpikir kritis matematis siswa, mempertimbangkan betapa diperlukannya kemampuan berpikir kritis bagi siswa di era ini. Berbeda dari penelelitian-penelitian sebelumnya, penelitian ini menggunakan sistem online dalam proses pengumpulan data dikarenakan kondisi yang diakibatkan oleh pandemik covid-19 sekarang ini. Instrumen yang digunakan dalam penelitian ini mengunakan indikator yang sesuai dengan kriteria indikator self-confidence dan kemampuan berpikir kritis oleh Hendriana dkk. (2017) sebagai berikut.

Tabel 1. Indikator Self-Confidence dan Kemampuan Berpikir Kritis

\begin{tabular}{ll}
\hline Indikator self-confidence & Indikator kemampuan berpikir kritis \\
\hline Percaya pada kemampuan diri sendiri & Memeriksa kebenaran pernyataan \\
Bertindak mandiri dalam mengambil & Mengamati dengan cermat dan memberi penjelasan/alasan \\
keputusan & atas jawaban \\
Menghargai diri dan usaha sendiri & Mengevaluasi situasi matematis \\
Berani menghadapi tantangan & Menganalisa dan membuat pernyatan dari situasi \\
\hline
\end{tabular}

\section{METODE PENELITIAN}

Jenis penelitian ini adalah deskriptif eksploratif dengan menggunakan pendekatan kualitatif. Pendekatan kualitatif merupakan prosedur penelitian yang menyajikan data kualitatif guna menyokong peneliti menganalisa dan memahami makna fenomena sosial yang terjadi. Sedangkan penelitian deskriptif eksploratif sendiri bukan ditujukan untuk menguji hipotesis namun untuk menggambarkan fenomena tertentu dimana dalam penelitian ini adalah kemampuan berpikir kritis matematis siswa berdasarkan selfconfidence yang dimiliki. Subjek yang digunakan dalam penelitian ini yaitu 3 orang siswa dari salah satu kelas X Akuntansi SMK Negeri 1 Kudus dengan masing-masing subjek memiliki self-confidence tinggi, self-confidence sedang, dan self-confidence rendah.

Pemilihan subjek penelitian diambil dari populasi siswa kelas X Akuntansi SMK Negeri 1 Kudus. Langkah awal dalam pemilihan subjek penelitian yaitu menetapkan 1 kelas yang akan dijadikan sebagai kelas penelitian yaitu kelas X Akuntansi 2 kemudian memberikan angket self-confidence via google form kepada kelas tersebut. Langkah selanjutnya, ditetapkan tingkat self-confidence siswa menjadi 3 kelompok. Siswa dibgi menjadi 3 kelompok tingkatan self-confidence dengan pembagian kelompok berdasarkan jumlah skor yang diperoleh siswa yang kemudian dikonversi menjadi kategori tinggi, sedang dan rendah 
dengan ketentuan yang diadaptasi dari langkah-langkah penjabaran Arikunto dalam Agryvita dkk. (2019) seperti pada tabel berikut.

Tabel 2. Pengelompokan Tingkat Self-Confidence Siswa

\begin{tabular}{cl}
\hline Skor & Kelompok \\
\hline$x \geq 106,01$ & Tinggi \\
$78,54<106,1$ & Sedang \\
$x \leq 78,54$ & Rendah \\
\hline
\end{tabular}

Keterangan : $\quad * 78,54$ : Nilai rata-rata - nilai standar deviasi

*106,01 : Nilai rata-rata + nilai standar deviasi

Dari hasil pengelompokan tingkat self-confidence siswa, tiap kelompok diambil satu subjek penelitian dengan mempertimbangkan nilai dari hasil pengisian angket self-confidence dan kemampuan mengutarakan argumen, pendapat, opini atau jalan pikiran siswa secara lisan. Di samping itu, pemilihan subjek juga mempertimbangkan kesediaan dari siswa. Selanjutnya, dari masing-masing kelompok dipilih secara purposive 1 subjek untuk dianalisis kemampuan berpikir kritis matematisnya sehingga ditetapkan 3 siswa sebagai subjek dalam penelitian, yaitu subjek dengan tingkat self-confidence tinggi, sedang, dan rendah. Dari hasil pengisian angket self-confidence, didapatkan data terkait tingkat selfconfidence siswa kelas X Akuntansi 2 yang telah diurutkan sesuai tingkatan self-confidence sebagai berikut.

Tabel 3. Urutan Tingkat Kepercayaan Diri Siswa Kelas X Akuntansi 2

\begin{tabular}{lllllll}
\hline Siswa & Nilai & Kelompok & & Siswa & Nilai & Kelompok \\
\cline { 1 - 3 } \cline { 5 - 6 } AW & 120 & Tinggi & RDS & 91 & Sedang \\
SKN & 119 & Tinggi & SGG & 90 & Sedang \\
MFF & 112 & Tinggi & RBN & 89 & Sedang \\
ANH & 109 & Tinggi & AM & 88 & Sedang \\
SIL & 108 & Tinggi & FNI & 88 & Sedang \\
MNH & 102 & Sedang & CAN & 87 & Sedang \\
IMP & 101 & Sedang & AD & 87 & Sedang \\
NS & 100 & Sedang & RMA & 85 & Sedang \\
DPM & 100 & Sedang & DAP & 83 & Sedang \\
AFN & 98 & Sedang & CKL & 80 & Sedang \\
LCN & 98 & Sedang & HMN & 79 & Sedang \\
HBDR & 96 & Sedang & MAI & 72 & Rendah \\
TRJ & 95 & Sedang & ARH & 70 & Rendah \\
FZ & 94 & Sedang & FO & 68 & Rendah \\
CRS & 93 & Sedang & YFN & 67 & Rendah \\
\hline
\end{tabular}

Keterangan : kotak berwarna hijau adalah subjek terpilih

Setelah melaksanakan tahap-tahap pengambilan subjek tersebut, maka diperoleh 3 peserta didik sebagai subjek penelitian ini, yaitu AW dengan tingkat self-confidence tinggi, RBN dengan tingkat self-confidence sedang, dan subjek YFN dengan tingkat self-confidence rendah. 
Penelitian ini melakukan pengumpulan data dengan teknik tes dan non tes. Pemberian tes bertujuan memperoleh data kemampuan berpikir kritis matematis siswa. Soal-soal dalam tes berbentuk uraian berjumlah 5 nomor, yang dirancang sesuai dengan indikator berpikir kritis matematis materi Peluang. Untuk mengumpulkan data dengan teknik non tes digunakan angket berisi kolom check list yang diberikan via google form untuk mengukur self-confidence siswa serta pedoman interview yang ditujukan agar memperoleh seluruh informasi secara langsung oleh subjek penelitian. Wawancara ini dilaksanakan untuk mengetahui tingkat self-confidence dan proses berpikir kritis matematis siswa.

Pemrosesan dan analisis data penelitian ini dilaksanakan secara bertahap yaitu dengan reduksi data, penyajian data, dan penarikan kesimpulan. Adapun teknik triangulasi digunakan untuk abalisis keabsahan data penelitian ini. Triangulasi waktu dilaksanakan dengan cara memberikan tes dan wawancara yang relatif sama sebanyak 2 kali dengan waktu yang berbeda dengan sumber yang sama. Dengan menggunakan triangulasi waktu maka diharapkan dapat diperoleh data yang valid.

\section{HASIL DAN PEMBAHASAN}

Pada penelitian ini, data yang diolah adalah data kualitatif yang didapat dari hasil tes kemampuan berpikir kritis matematis serta wawancara subjek. Instrumen yang diujikan adalah tes uraian bab peluang berjumlah 5 soal. Sedangkan Wawancara dilaksanakan untuk mengetahui tingkat self-confidence dan proses berpikir kritis matematis subjek penelitian. Agar mendapatkan data yang valid, juga dilaksanakan triangulsi waktu melalui pengadaan tes dan interview sebanyak 2 kali dengan materi yang relatif sama namun dengan waktu yang berbeda terhadap setiap subjek penelitian. Berikut adalah tabulasi data hasil penelitian ini.

Tabel 4. Kemampuan Berpikir Kritis Matematis Siswa Berdasarkan Self-Confidence

\begin{tabular}{|c|c|c|c|c|c|}
\hline \multirow[b]{2}{*}{$\begin{array}{l}\text { Nomor } \\
\text { soal }\end{array}$} & \multirow{2}{*}{\multicolumn{2}{|c|}{ Indikator soal berpikir kritis }} & \multicolumn{3}{|c|}{ Subjek Dengan Self-Confidence } \\
\hline & & & $\begin{array}{l}\text { Tinggi } \\
\text { (AW) }\end{array}$ & $\begin{array}{l}\text { Sedang } \\
\text { (RBN) }\end{array}$ & $\begin{array}{l}\text { Rendah } \\
\text { (YFN) }\end{array}$ \\
\hline 1 & Memeriksa kebenaran pern & & & & \\
\hline 2 & $\begin{array}{l}\text { Mengamati dengan cermat } \\
\text { penjelasan/alasan atas jawa }\end{array}$ & memberi & & & \\
\hline 3 & Mengevaluasi situasi maten & & & & \\
\hline 4 & Menganalisa dan membuat & lyatan dari situasi & & & \\
\hline \multirow[t]{2}{*}{ Keteranga } & an : & Dimiliki & & & \\
\hline & & Tidak dimiliki & & & \\
\hline
\end{tabular}

Subjek dengan Self-Confidence Tinggi (AW). Subjek yang memiliki self-confidence tinggi mampu menyelesaikan semua soal dari keempat indikator dengan jawaban yang rinci dan runtut tiap poin soalnya. Hal tersebut menunjukkan bahwa subjek memiliki pemikiran matematis yang kritis karena memenuhi seluruh indikator yang diujikan. Siswa tersebut mampu memeriksa kebenaran pernyataan, mengamati dengan cermat dan memberikan penjelasan atas jawabannya, mengevaluasi situasi matematis pada soal, serta mampu menganalisa dan membuat pernyataan dari situasi soal yang dihadapi karena ia percaya dengan kemampuan yang dimiliki sehingga dapat menyelesaikan semua soal yang diberikan dengan maksimal. 
Kondisi di atas sesuai dengan hasil penelitian yang dilakukan oleh Nurkholifah, dkk. (2018) yang mengungkapkan bahwa tingkat kepercayaan diri siswa berbanding lurus dengan kemampuan berpikir kritisnya. Serta didukung juga oleh Tresnawati, dkk. (2017) dalam penelitiannya yang menytakan bahwa self-confidence memberikan cukup banyak kontribusi terhadap kemampuan berpikir kritis matematis siswa SMA di Kota Bandung. Sehingga hasil penelitian ini menunjukkan bahwa subjek memiliki pemikiran kritis matematis yang tinggi karena mampu memenuhi 4 indikator diujikan dalam soal tes.

Subjek dengan Self-Confidence Sedang (RBN). Subjek yang memiliki self-confidence sedang mampu menyelesaikan 2 soal dari 4 soal yang diberikan yaitu soal pertama dan ketiga. Subjek ini mampu mengerjakan 3 soal dengan jawaban yang cukup rinci dan runtut namun pada soal ketiga terdapat kesalahan pemahaman soal di awal karena kekurangtelitian subjek yang menyebabkan tidak tepatnya jawaban dari atas hingga bawah. Dan karena manajemen waktu yang kurang baik, soal nomor 4 tidak mampu diselesaikan oleh siswa tersebut.

Hal tersebut sesuai dengan hasil penelitian yang dilakukan oleh Nurkholifah, dkk. (2018:58) yang mengungkapkan bahwa terdapat hubungan positif antara self-confidence dan kemampuan berpikir kritis matematis siswa, dimana semakin tinggi self-confidence yang dimiliki siswa maka akan semakin tinggi pula kemampuan berpikir kritis matematis siswa, begitupun sebaliknya. Sehingga hasil penelitian tersebut menunjukkan bahwa subjek memiliki pemikiran kritis matematis yang sedang atau cukup baik karena memenuhi 2 indikator dari 4 indikator yang diujikan. Siswa tersebut mampu memeriksa kebenaran pernyataan, mengevaluasi situasi matematis pada soal, namun kurang cermat dalam mengamati dan memberikan penjelasan atas jawabannya, serta belum mampu menganalisa dan membuat pernyataan dari situasi soal yang dihadapi.

Subjek dengan Self-Confidence Rendah (YFN). Subjek yang memiliki self-confidence rendah hanya mampu menyelesaikan soal pertama dari 4 soal yang diberikan. Meskipun jawaban yang diberikan cukup rinci dan runtut namun hanya soal pertama yang bisa dikerjakan dikarenakan manajemen waktu yang buruk dan ketidakpercayaan pada dirinya terlihat dari bagaimana ia berhenti mengerjakan soal pertama karena merasa tidak mampu, kemudian mencoba melanjutkan soal berikutnya dan terulang lagi hingga kembali pada nomor pertama. Kekonsistenan dan kefokusan subjek yang buruk dalam menyelesaikan soal menunjukkan bahwa ia kurang percaya dalam kemapuannya. Selain itu, subjek juga beberapa kali bertanya kepada temannya dalam proses pengerjaan karena kurang percaya denan kemampuannya sendiri.

Kondisi di atas sesuai dengan hasil penelitian yang dilakukan oleh Hajar dan Minarti (2019) pada siswa kelas IX di salah satu SMP swasta di Kota Cimahi dimana mengungkapkan bahwa siswa cenderung memiliki tingkat kemampuan berpikir kritis matematis rendah yang diakibatkan karena kurangnya rasa percaya diri (self-confidence) ketika menghadapi matematika. Jadi, berdasarkan hasil penelitian tersebut dapat dikatakan bahwa subjek memiliki pemikiran kritis matematis yang rendah karena hanya mampu mencapai 1 indikator dari 4 indikator yang diujikan. Siswa tersebut hanya mampu memeriksa kebenaran pernyataan, namun belum mampu mengevaluasi situasi matematis pada soal, dan kurang cermat dalam mengamati dan memberikan penjelasan atas jawabannya, serta belum mampu menganalisa dan membuat pernyataan dari situasi soal yang dihadapi. 


\section{SIMPULAN DAN SARAN}

Berdasarkan uraian pada hasil penelitian dan pembahasan, didapatkan simpulan guna menjawab rumusan masalah penelitian sebagai berikut. Pertama, siswa dengan selfconfidence tinggi mempunyai kemampuan berpikir kritis matematis yang sangat baik, dibuktikan dengan telah dilampauinya 4 indikator berpikir kritis matematis yang diujikan. Kedua, siswa dengan self-confidence sedang mempunyai kemampuan berpikir kritis matematis yang sedang atau cukup baik, karena telah mencapai 2 indikator dari 4 indikator berpikir kritis matematis yang diujikan, yaitu mampu memeriksa kebenaran pernyataan dan mengevaluasi situasi matematis pada soal. Ketiga, siswa dengan self-confidence rendah mempunyai kemampuan berpikir kritis matematis yang kurang baik, karena hanya mampu melalui 1 tahapan/indikator berpikir kritis matematis, yaitu mampu memeriksa kebenaran pernyataan.

Adapun saran yang dapat diberikan peneliti yaitu sebagai berikut. Pertama, guru hendaknya memfasilitasi siswa banyak latihan soal yang dapat mningkatkan kemampuan berpikir kritis matematis siswa. Kedua, siswa hendaknya meng-upgrade self-confidence yang dimiliki dalam pembalajaran matematika agar mampu mengembangkan kemampuan berpikir kritisnya. Ketiga, diharapkan adanya penilitian yang lebih optimal terkait kemampuan berpikir kritis siswa baik ditinjau dari aspek self-confidence maupun aspek lainnya.

\section{DAFTAR RUJUKAN}

Agryvita, Busnawir, \& Sahidin, L. (2019). Pengaruh Kepercayaan Diri Terhadap Kemampuan Berpikir Kritis Matematis Siswa. Presentasi pada Prosiding Seminar Nasional Pendidikan Matematika II, Universitas Halu Oleo Kampus Hijau Bumi Tridharma Andounohu Kendari.

Agusman. (2016). "Desain Model Pembelajaran Matematika yang Mengembangkan Kemampuan Berpikir Kritis.” Jurnal Pendidikan Matematika 2(2) 111-121.

Danaryanti, A., \& Lestari, T. (2017). Analisis Kemampuan Berpikir Kritis dalam Matematika Mengacu pada Watson-Glaser Critical Thinking Appraisal pada Siswa Kelas VIII SMP Negeri di Banjarmasin Tengah Tahun Pelajaran 2016/2017. Jurnal EDU-MAT 5(2) 116-126.

Hajar, Siti, M., \& Minarti, E. D. (2019). Pengaruh Self Confidence Siswa SMP Terhadap Kemampuan Berpikir Kritis Matematis, Jurnal Majamath 2(1) 1-6.

Hendriana, H., Rohaeti, E. E, \& Sumarno, U. (2017). Hard Kemampuan dan Soft Kemampuans Matematik Siswa. Bandung: PT. Refika Aditama.

Hidayat. (2017). Adversity Quotient dan Penalaran Kreatif Matematis Siswa SMA dalam Pembelajaran Argument Driven Inquiry pada Materi Turunan Fungsi. Kalamatika: Jurnal pendidikan matematika 2(1) 15-28.

Manfaati, Kh. (2017). Analisis Kemampuan Berpikir Kritis Siswa SMP dalam Pembelajaran Matematika Berdasarkan Gaya Belajarnya. Skripsi, Jurusan Matematika, Fakultas Matematika dan Ilmu Pengetahuan Alam, Universitas Negeri Semarang.

Martyanti, A. (2013). Membangun Self-Confidence Siswa Dalam Pembelajaran Matematika dengan Pendekatan Problem Solving. Prosiding Seminar Nasional Matematika dan Pendidikan Matematika Jurusan Pendidikan Matematika, UNY. 
Muhtadi, D., Supratman \& Hermanto, R. (2019). The students' mathematical critical thinking process reviewed from the cognitive style. Journal of Physics: Conference Series, doi:10.1088/1742-6596/1188/1/012082

Nurkholifah, Siti, Toheri, \& Winarso, W. (2018). Hubungan antara Self Confidence dengan Kemampuan Berpikir Kritis Siswa dalam Pembelajaran Matematika. Edumatica 8(1) 58-66.

Purwati, Ratna, Hobri, \& Fatahillah, A. (2016). Analisis Kemampuan Berpikir Kritis Siswa dalam Menyelesaikan Masalah Persamaan Kuadrat pada Pembelajaran Model Creative Problem Solving. Jurnal Kadikma 7(1) 84-93.

Septiani, Tamia, Hudanagara, M. A., Hendriana, H., \& Anita, I. W. (2018). Pengaruh Self Confidence dan Self Efficacy Terhadap Kemampuan Berpikir Kreatif Matematis Siswa SMP. Jurnal Pembelajaran Matematika Inovatif (JPMI) 1(2).

Tresnawati, Hidayat, W., \& Rohaeti, E. E. (2017). Kemampuan Berpikir Kritis Matematis dan Kepercayaan Diri Siswa SMA. Pasundan Journal of Research in Mathematics Learning and Education (Symmetry) 2(2) 116-122.

Widana, I. W. (2018). Higher Order Thinking Kemampuans Assessment toward Critical Thinking on Mathematics Lesson. International Journal of Social Sciences and Humanities 2(1) 24-32.

Wulandari \& Putri, I. (2019). Berpikir Kritis Matematis dan Kepercayaan Diri Siswa Ditinjau dari Adversity Quotient. PRISMA 2(2) 629-636.

Zetriuslita, Rezi \& Nufus. (2016). Analisis Kemampuan Berpikir Kritis Matematis Mahasiswa Dalam Menyelesaikan Soal Uraian Kalkulus Integral Berdasarkan Level Kemampuan Mahasiswa. Jurnal Ilmiah Program Studi Matematika STKIP Siliwangi Bandung, 5(1) 56-65. 